\title{
Measurement of a Newly Developed Thrombomodulin Addition Activated Partial Thromboplastin Time Assay in Patients with Deep Venous Thrombosis
}

\author{
Etsuji Suehisa $^{a}$ Masayuki Toku $^{a}$ Tomio Kawasaki $^{b}$ \\ Yuzuru Kanakura ${ }^{a}$

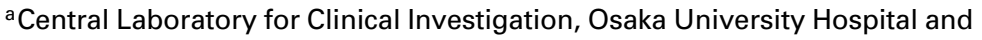 \\ bDepartment of Surgery II, Osaka University Medical School, Suita, Osaka, Japan
}

\section{Key Words}

Thrombomodulin P Protein C · Protein S

\begin{abstract}
We developed a simple assay using rabbit thrombomodulin (TM) based on an activated partial thromboplastin time method, which detected the response to TM in plasma coagulation. We call it thrombomodulin addition clotting time (TACT). The anticoagulant response to TM was calculated by dividing the clotting time with TM by the clotting time with buffer solution. Results were expressed as TACT ratio, which indicates the degree of inhibition of plasma clotting by TM. Using this assay, we measured the TACT ratio in 80 patients with deep-vein thrombosis (DVT) and in 126 controls matched to the patients according to age and sex. A significant difference in the TACT ratio was observed between patients with DVT (mean 1.874) and controls (mean 1.956) ( $p<0.001$ ). Twenty-
\end{abstract}

three patients (29\%) had TACT ratios below the 10th percentile (1.757) of distribution of control subjects (odds ratio: 3.5 ; $95 \%$ confidence interval ( $\mathrm{Cl}$ ): 1.7-7.2). After excluding subjects with a deficiency of protein C, protein $\mathrm{S}$ and antithrombin III, we found an odds ratio for DVT of 3.4 (95\% Cl: 1.6-7.2). These data suggest that natural anticoagulant deficiencies do not influence the TACT ratio, and our case-control study may show that the plasma of patients with DVT has a low response to TM.

Copyright $\odot 2001$ S. Karger AG, Basel

\section{Introduction}

The blood coagulation system is regulated by cofactors and anticoagulant proteins in plasma [1-7]. Protein C (PC) and protein S (PS) play an important role in downregulation of coagulation. Thrombomodulin (TM) is an endothelial-cell surface-bound cofactor in

\begin{tabular}{ll}
\hline KARGER & ○ 2001 S. Karger AG, Basel \\
$\begin{array}{l}\text { Fax +41 61306 1234 } \\
\begin{array}{l}\text { E-Mail karger@karger.ch } \\
\text { www.karger.com }\end{array}\end{array}$ & $\begin{array}{l}\text { Accessible online at: } \\
\text { www.karger.com/journals/hae }\end{array}$
\end{tabular}

\footnotetext{
Etsuji Suehisa

Central Laboratory for Clinical Investigation, Osaka University

Hospital, 2-15 Yamada-oka, Suita, Osaka 565-0871 (Japan)

Tel. +8166879 6655, Fax +8166879 6657

E-Mail esuehisa@hp-lab.med.osaka-u.ac.jp
} 
thrombin-dependent formation of activated PC (APC) and downregulates blood coagulation by proteolytic inactivation of procoagulant cofactors Va and VIIIa with APC in the presence of its cofactor PS. It is well established that patients who are deficient in PC and PS have a risk for venous thromboembolism [8-11]. A previous study has reported that the frequency of TM mutations among patients with thromboembolic disease is approximately $5 \%[12]$. It is expected that abnormality of TM function is also related to development of venous thrombosis.

We describe a simple assay called thrombomodulin addition clotting time (TACT) based on an activated partial thromboplastin time (aPTT) method for detecting the response of TM function. In order to analyze the relation between normal control and deep-vein thrombosis (DVT) patients, we performed a case-control study using this assay.

\section{Patients and Methods}

\section{Patients and Controls}

The study population comprised 80 consecutive patients with DVT (41 men and 39 women, age 17-84 years (mean 50 years)), and 126 normal volunteers (66 men and 60 women, age $16-87$ years (mean 50 years)). Patients were referred to the Department of Surgery II at Osaka University Hospital during a 38-month period (August 1991 through October 1994). The investigation was performed at least 3 months after the thrombotic episode. For patients on oral anticoagulant therapy, screening was carried out after cessation of anticoagulation therapy for at least 4 weeks. Diagnosis of DVT was made based on clinical manifestations and findings from duplex scanning, radioisotope venography, and contrast venography. The two groups were matched in terms of age and sex, with no significant differences in these variables.

\section{Blood Samples}

Venous blood samples were collected by venipuncture using a tourniquet in Vacutainer tubes containing $3.2 \%(\mathrm{w} / \mathrm{v})$ trisodium citrate $(0.129 M ; 9: 1, \mathrm{v} / \mathrm{v})$. Platelet-poor plasma was prepared by centrifugation at
$2,800 \mathrm{~g}$ for $10 \mathrm{~min}$, and the plasma was kept at $-80^{\circ} \mathrm{C}$ until use.

\section{Assay of TACT}

Rabbit TM was purified from rabbit lungs as has been described elsewhere [13]. The amount of TM was determined by preliminary experiments to prolong aPTT twice the normal value obtained with pooled normal plasma. TACT was measured on the basis of the aPTT. Either $30 \mu \mathrm{l}$ of $100 \mu \mathrm{g} / \mathrm{ml}$ TM or a buffer solution containing $0.15 \mathrm{M} \mathrm{NaCl}, 0.5 \%$ Triton X-100, $50 \mathrm{~m} M$ Tris- $\mathrm{HCl} \mathrm{pH} 7.4$ was mixed with $60 \mu \mathrm{l}$ of plasma. After incubation at $37^{\circ} \mathrm{C}$ for $1 \mathrm{~min}, 100 \mu \mathrm{l}$ of aPTT reagent (Actin; DADE, Miami, Fla., USA) was added and incubated at $37^{\circ} \mathrm{C}$ for $5 \mathrm{~min}$. The coagulation reaction was started by adding $100 \mu 125 \mathrm{mM}$ $\mathrm{CaCl}_{2}$. The clotting time was measured with an Amelung KC-10A (Heinrich Amelung GmbH, Lemgo, Germany). The TACT ratio was calculated by dividing clotting time with TM by the clotting time with buffer solution.

\section{Measurements of PS and PS}

The activity of $\mathrm{PC}$ was determined by chromogenic substrate assay kit employing PGPA-MNA (Berichrom; Behringwerke, Marburg, Germany). The activity of PS was measured by clotting assay using activated factor V (Staclot protein S; Diagnostica Stago, Asnières, France).

\section{Statistical Analysis}

On the TACT ratio or aPTT, Mann-Whitney test was used to compare the distribution of normal subjects and patients. A $p$ value of $\leq 0.05$ was considered statistically significant. We calculated odds ratios as estimates of relative risk and $95 \%$ confidence interval (CI) by statistical program StatFlex (Artech Inc., Osaka, Japan), also a cut-off point using a receiver-operating characteristics (ROC) curve was calculated by this statistical program.

\section{Results}

We determined the intra- and interassay reproducibility using aliquots stored at $-80^{\circ} \mathrm{C}$ from normal plasma. The variation coefficients were $1.7 \%(\mathrm{n}=10$, mean 1.943$)$ and $2.6 \%(n=5$, mean 2.058$)$ respectively. To test the influence of storage, normal plasma was analyzed before freezing then stored at 


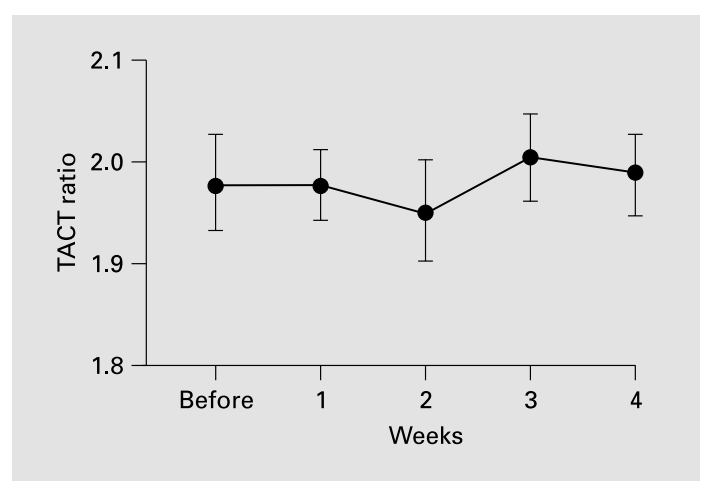

Fig. 1. Influence of storage at $-80^{\circ} \mathrm{C}$ on TACT ratio. Data are expressed as the mean \pm SD of 5 times measured values using plasma from a normal subject.

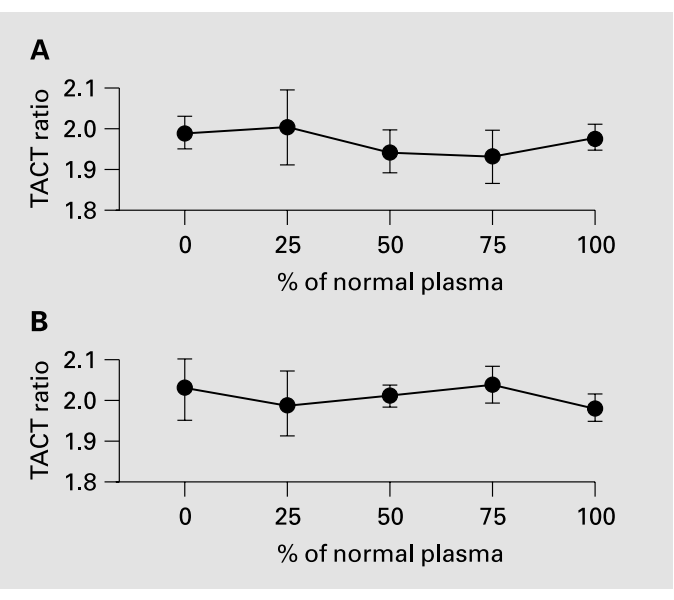

Fig. 2. Influence of PC or PS concentration on TACT ratio. Data are expressed as the mean \pm SD of 5 times measured values. Normal plasma was added to (A) PC-deficient plasma or (B) PS-deficient plasma $(0,25$, 50 and $100 \%$ of normal plasma) and the TACT ratio analyzed.

$-80^{\circ} \mathrm{C}$ and analyzed repeatedly over 4 weeks. TACT ratios were not changed after the storage at $-80^{\circ} \mathrm{C}$ over 4 weeks (fig. 1).

To test the influence of PC or PS concentration, normal plasma was added to PC-defi- cient plasma (Diagnostica Stago) or PS-deficient plasma (Biopool, Burlington, Canada) $(0,25,50$ and $100 \%$ of normal plasma $)$ and then analyzed TACT ratio. TACT ratios were not changed when using both PC- and PSdeficient plasma (fig. 2). There was no significant difference between aPTT values in patients (mean 28.1 s) with DVT and those in normal subjects (mean $28.4 \mathrm{~s}$ ).

The figure 3 shows the TACT ratios of patients with DVT and those of controls. The median TACT ratio in the patients was 1.840, while that in the controls was 1.939. TACT ratios in the patients (mean 1.874) were lower than those in the controls (mean 1.956) $(\mathrm{p}<$ 0.001).

As a cut-off point, we used the 10th percentile of distribution for control subjects. The 10th percentile of TACT ratios in the control group was 1.757. Among the patients, 23 (29\%) had a TACT ratio below the cut-off point. This yields an odds ratio of 3.5 (95\% CI: 1.7-7.2). Of the 80 patients, 2 had AT-III deficiency, 4 had PC deficiency, and 6 had PS deficiency. After excluding these subjects, we found the odds ratio for DVT to be 3.4 (95\% CI: 1.6-7.2). This result shows that TACT ratio is independent of these deficiencies (table 1). The odds ratios for several other cut-off points are shown in table 2 .

To evaluate the possibility of a levelresponse relation, we stratified the TACT ratios of both patients and controls into quartiles and calculated the odds ratios for the three higher levels, and compared them to the lower reference level. As table 3 shows, the risk of thrombosis did not increase among subjects with TACT ratios $>1.8$. The risk was greatly increased $<1.8$. Furthermore, a cut-off point which was calculated from sensitivity and specificity using a ROC curve was 1.89 , and the odds ratio was 2.8 when a TACT ratio below the cut-off point was used. 
Fig. 3. Correlation of TACT ratio in patients and controls. Solid lines indicate median values; dotted lines indicate 10th percentiles from the low value of distribution of control subjects.

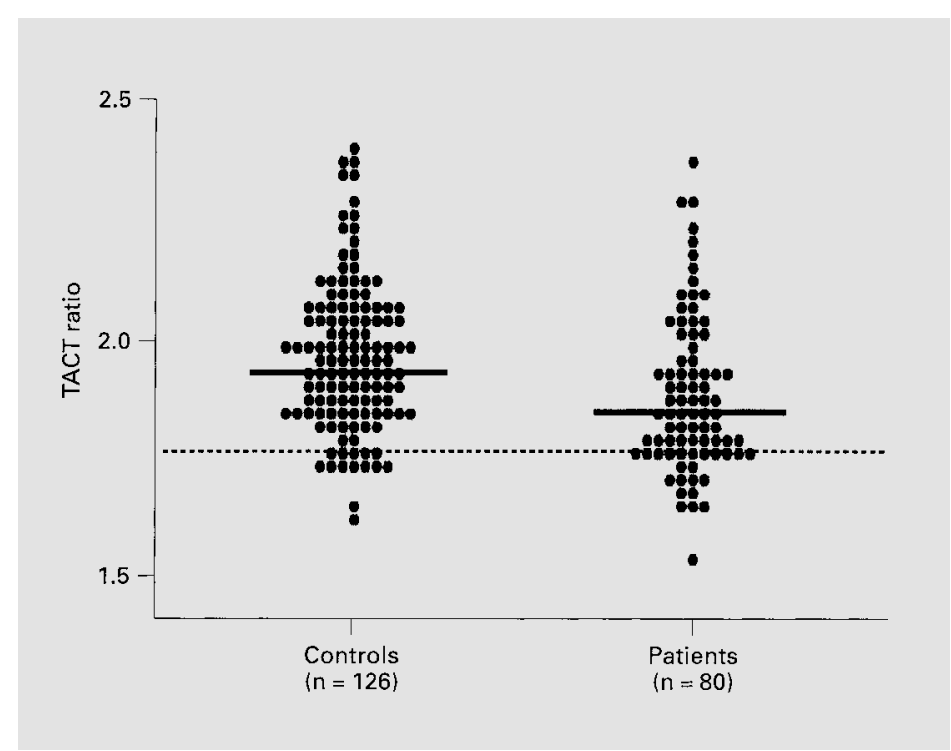

Table 1. TACT ratio and risk of DVT

\section{Cases Controls Odds ratio $95 \% \mathrm{CI}$}

\begin{tabular}{|c|c|c|c|c|}
\hline & Cases & Controls & Odds ratio & $95 \% \mathrm{CI}$ \\
\hline \multicolumn{5}{|c|}{ Including PC, PS and AT-III deficiencies } \\
\hline$\leq 10$ th percentile $(1.757)$ & 23 & 13 & \multirow{2}{*}{3.5} & \multirow{2}{*}{$1.7-7.4$} \\
\hline$>10$ th percentile $(1.757)$ & 57 & 113 & & \\
\hline \multicolumn{5}{|c|}{ Excluding PC, PS and AT-III deficiencies } \\
\hline$\leq 10$ th percentile $(1.757)$ & 19 & 13 & \multirow{2}{*}{3.4} & \multirow{2}{*}{$1.5-7.4$} \\
\hline$>10$ th percentile $(1.757)$ & 49 & 113 & & \\
\hline
\end{tabular}

Median (interquartile): 1.934 (0.212) for controls, $1.840(0.187)$ for cases.

Table 2. DVT for different cut-off points of TACT ratio

\begin{tabular}{lll}
\hline & Odds ratio & $95 \% \mathrm{CI}$ \\
\hline 2.5th percentile (1.722) & 4.4 & $1.3-14.4$ \\
5.0th percentile $(1.759)$ & 3.2 & $1.1-9.0$ \\
10th percentile $(1.757)$ & 3.5 & $1.7-7.4$ \\
20th percentile $(1.827)$ & 3.5 & $2.0-6.0$ \\
40th percentile $(1.897)$ & 2.8 & $1.6-5.1$ \\
\hline
\end{tabular}

Thrombomodulin Addition Clotting Time and DVT

\section{Discussion}

Major risk factors for DVT are thrombotic disorders, stasis and immobilization, and hematological disorders. Unrecognized risk factors for DVT still remain. Previous studies have shown that abnormality in the PC pathway is a main risk factor for development of thrombotic disorders [14-16]. Our assay indicates the degree of inhibition of plasma clot-

Haemostasis 2001;31:26-31 
Table 3. Thrombosis risk for strata of TACT ratio

\begin{tabular}{llllll}
\hline & $\begin{array}{l}\text { Cases } \\
(\mathrm{n}=80)\end{array}$ & $\begin{array}{l}\text { Controls } \\
(\mathrm{n}=126)\end{array}$ & $\begin{array}{l}\text { Total } \\
(\mathrm{n}=206)\end{array}$ & Odds ratio & 95\% CI \\
\hline 1st quartile $<1,800$ & 34 & 17 & 51 & 6.0 & $2.5-14.0$ \\
2nd quartile 1,800-1,900 & 18 & 34 & 52 & 1.6 & $0.7-3.7$ \\
3rd quartile 1,900-2,025 & 15 & 36 & 51 & 1.3 & $0.5-3.0$ \\
4th quartile $>2,025$ & 13 & 39 & 52 & 1.0 & \\
\hline
\end{tabular}

The reference category comprised the subjects with a TACT ratio $>2.025$.

ting by TM. We found an increasing odds ratio as TACT ratio decreased. For individuals with TACT ratio $<1.8$, the risk of thrombosis was 6 times higher than that for subjects in the reference category $(>2.025)$. This highrisk stratum consisted of $43 \%$ of patients and $13 \%$ of controls. The $43 \%$ prevalence of TACT ratio $<1.8$ among DVT patients at high risk for thrombosis leads to the conclusion that a low TACT ratio is an important marker of thrombosis.

A similar study by Duchemin et al. [17] demonstrated that an assay based on thrombin generation inhibition by rabbit TM was useful to detect deficiencies in both PC and PS. In our assay, TACT ratio was not influenced by PC and PS concentration. It has been reported that the mechanism for anticoagulant activity is the direct action of TM on thrombin and the indirect effect of activated PC. Our results suggest that a low TACT value is not due to activation of the PC pathway. As the clotting time in our assay was very short, there may not have been sufficient time to activate PC [22].

Moreover, TM directly blocks thrombincatalyzed fibrinogen clotting, factor $\mathrm{V}$ activation, platelet activation $[18,19]$ and procoagulant activity of factor Xa [20,21]. Preissner et al. [22] reported that the direct interference of TM function affected high molecular polycations such as the releasate from platelet, known to contain several glycosaminoglycan-binding proteins such as platelet factor 4 , histidine-rich glycoprotein, fibronectin and thrombospondin. In our patients, the presence of these polycations in plasma from platelet activation following thrombosis development cannot be denied. However, in their study, Preissner et al. [22] used a high concentration of platelet releasate from ionophore-treated platelets, and the presence of such high levels of polycation in plasma is difficult to expect in DVT patients.

Our assay may have detected the response to these functions, and such decreasing TM functions suggest that inhibitors exist in plasma.

Some studies have shown the existence of autoantibodies to TM in patients with autoimmune disease or lupus anticoagulation to be positive [23-25]. Recently, Carson et al. [26] reported that autoantibodies to TM existed in $10 \%$ of patients with unexplained thrombosis, and a prolonged overnight incubation with antigen was required for detection of these antibodies by ELISA. Our patients did not have autoimmune disease, and all were negative for cardiolipin antibodies. Moreover, the incubation time of the plasma and TM mixture in our assay was short. The examination is more necessary when a low 
TACT ratio in our patients is due to antibodies to TM.

We conclude that our assay method detected the abnormality of TM response in plasma coagulation, and plasma of patients with DVT may have a low response to TM.

\section{Acknowledgment}

We thank Mr. Hachiro Yamanishi (Central Laboratory for Clinical Investigation, Osaka University Hospital) for technical support with the statistical analysis.

\section{References}

1 Furie B, Furie BC: The molecular basis of blood coagulation. Cell 1988;53:505-518.

2 Davie EW, Fujokawa K, Kisiel W: The coagulation cascade: Initiation, maintenance, and regulation. Biochemistry 1991;30:10363-10370.

3 Esmon CT: The roles of protein $\mathrm{C}$ and thrombomodulin in the regulation of blood coagulation. J Biol Chem 1989;264:4743-4746.

4 Bauer KA, Rosenberg RD: Role of antithrombin III as a regulator of in vivo coagulation. Semin Hematol 1991;28:10-18.

5 Rapaport SI: Inhibition of factor VIIa/tissue factor-induced blood coagulation: With particular emphasis upon a factor Xa-dependent inhibitory mechanism. Blood 1989;73: 359-365.

6 Mann KG, Jenny RJ, Krishnaswamy S: Cofactor proteins in the assembly and expression of blood clotting enzyme complexes. Annu Rev Biochem 1988;57:915-956.

7 Kane WH, Davie EW: Blood coagulation factors V and VIII: Structural and functional similarities and their relationship to hemorrhagic and thrombotic disorders. Blood 1998; 71:539-555.

8 Thaler E, Lechner K: Antithrombin III deficiency and thromboembolism. Clin Haematol 1981;10:369390.

9 Griffin JH, Evatt B, Zimmermann TS, Kleiss AJ, Wideman C: Deficiency of protein $\mathrm{C}$ in congenital thrombotic disease. J Clin Invest 1981;68:1370-1373.

10 Schmarz HP, Fisher M, Hopmeier $\mathrm{P}$, Batard MA, Griffin JH: Plasma protein $\mathrm{C}$ in familial thrombotic disease. Blood 1984;64:1297-1300.
11 Comp PC, Nixon PR, Cooper MR, Esmon CT: Familial protein S deficiency is associated with recurrent thrombosis. J Clin Invest 1984; 74 : 2082-2088.

12 Ohlin AK, Norlund L, Marlar RA: Thrombomodulin gene variations and thromboemoblic disesae. Thromb Haemost 1997;78:396400.

13 Esmon NL, Owen WG, Esmon CT: Isolation of a membrane-bound cofactor for thrombin-catalyzed activation of protein C. J Biol Chem 1982;257:859-864.

14 Bick RL, Pegram M: Syndromes of hypercoagulability and thrombosis: A review. Semin Thromb Hemost 1994;20:109-132.

15 Dahlback B: Physiological anticoagulation. Resistance to activated protein $\mathrm{C}$ and venous thromboembolism. J Clin Invest 1994;94:923927.

16 Sala N, Fontcuberta J, Rutllant MLL: New biological concepts on coagulation inhibitors. Intensive Care Med 1993;19:S3-S7.

17 Duchemin J, Pitte JL, Tartary M, Beguin S, Gaussen P, Alhenc-Gelas M, Aiach M: A new assay based on thrombin generation inhibition to detect both protein $\mathrm{C}$ and protein $\mathrm{S}$ deficiencies in plasma. Thromb Haemost 1994; 71:331-338.

18 Esmon CT, Esmon NL, Harris KW: Complex formation between thrombin and thrombomodulin inhibits both thrombin-catalyzed fibrin formation and factor $\mathrm{V}$ activation. $\mathrm{J}$ Biol Chem 1982;257:7944-7947.

19 Esmon NL, Carroll RC, Esmon CT: Thrombomodulin blocks the ability of thrombin to activate platelets. J Biol Chem 1983;258:12238-12242.
20 Thomspon EA, Hatem HS: Inhibition by thrombomodulin of factor Xa-mediated cleavage of thrombomodulin. J Clin Invest 1986;78:1317.

21 Rodgers GM, Greenberg CS, Shuman MA: Characterization of the effects of cultured vascular cells on the activation of blood coagulation. Blood 1983;61:1155-1162.

22 Preissner KL, Koyama T, Muller D, Tschopp J, Berghaus GM: Domain structure of the endothelial cell receptor thrombomodulin as deduced from modulation of its anticoagulant functions. J Biol Chem 1990; 265:4915-4922.

23 Gibson J, Nelson M, Brown R, Salem H, Kronenberg H: Autoantibodies to thrombomodulin: Development of an enzyme immunoassay and survey of their frequency in patients with the lupus anticoagulant. Thromb Haemost 1992;67:507509.

24 Oosting JD, Preissner KT, Derksen RHWM, de Groot PG: Autoantibodies directed against the epidermal growth factor-like domains of thrombomodulin inhibit protein $\mathrm{C}$ activation in vitro. Br $\mathrm{J}$ Haematol 1993;85:761-768.

25 Ruiz-Arguelles GJ, Ruiz-Arguelles A, Deleze M, Alarcon-Segovia D: Acquired protein $\mathrm{C}$ deficiency in a patient with primary antiphospholipid syndrome. Relationship to activity of anticardiolipin antibody with thrombomodulin. J Rheumatol 1989; 16:381-383.

26 Carson CW, Comp PC, Rezai AR, Esmon NL, Esmon CT: Antibodies to thrombomodulin are found in patients with lupus anticoagulant and unexplained thrombosis. J Rheumatol 2000;27:384-390. 